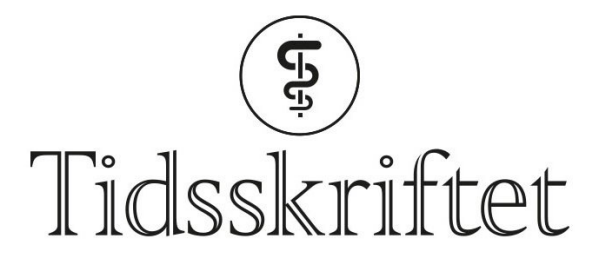

DEN NORSKE LEGEFORENING

\title{
Nyfødtomsorg som redder liv
}

FRA ANDRE TIDSSKRIFTER

KRISTOFFER BRODWALL

Barne- og ungdomsklinikken

Haukeland universitetssykehus

Overlevelsen for premature nyfødte i fattige land kan bedres betydelig ved å lære opp mødrene til å gi omsorg med hudkontakt og amming.

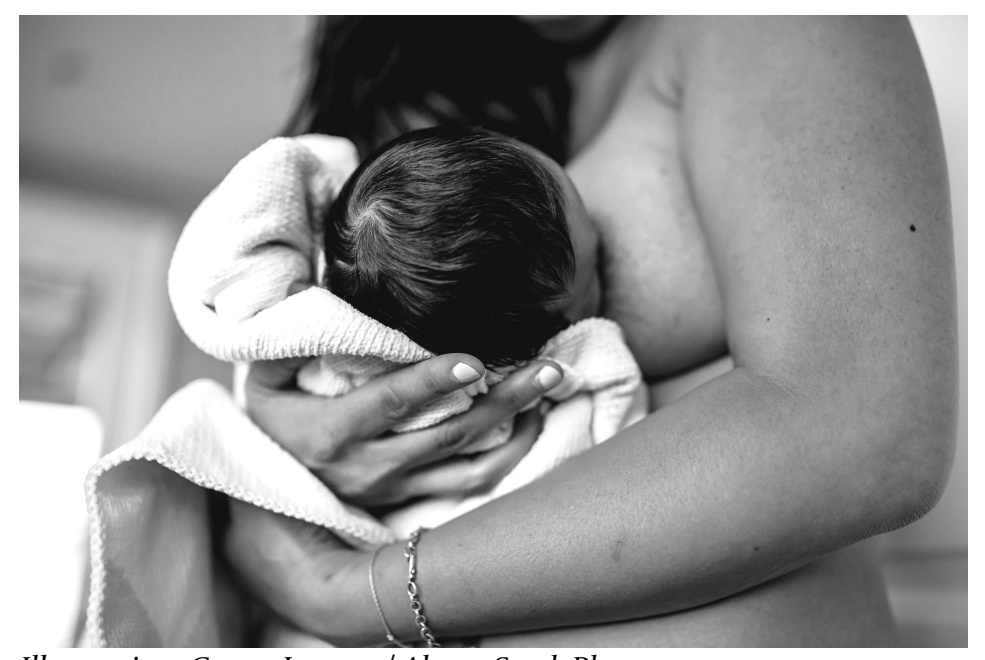

Illustrasjon: Cavan Images / Alamy Stock Photo

Ved den såkalte kengurumetoden for omsorg av nyfødte barn med lav fødselsvekt blir nybakte foreldre lært opp til å gi barnet hud-mot-hud-kontakt, og det gis råd om og bistand til fullamming. Tiltaket er vist å bedre overlevelse når det iverksettes på sykehus for nyfødte med fødselsvekt under 2 ooo g. Verdens helseorganisasjon anbefaler derfor kengurumetoden ved sykehusfødsler, men i mange land skjer en stor del av fødslene utenfor sykehus.

Blant dem som blir født på sykehus eller helseklinikker reiser mange hjem kort tid etter fødselen. Det er derfor antatt at kengurumetoden blir gjennomført for bare $5 \%$ av dem som burde fått det.

En fersk studie fra India har vurdert effekten av å promotere kengurumetoden i hjemmet (1). Rundt 8400 nyfødte med vekt på 1 500-2 $250 \mathrm{~g}$ ble randomisert til en intervensjonsgruppe som fikk hjemmebes $\emptyset \mathrm{k}$ av en veileder i kengurumetoden på dag 1, 2, 3, $5,7,10,14,21$ og 28, eller til en kontrollgruppe som fikk standard oppfølging. Barna var gjennomsnittlig 30 timer gamle ved inklusjon.

Innen 28 dagers alder hadde 73 av rundt 4400 barn (1,65\%) i intervensjonsgruppen dødd, mot 90 av drøyt 3850 barn (2,33\%) i kontrollgruppen. 180 dager etter fødselen var andelen 
henholdsvis 3,98 \% og 5,24\%. Dette tilsvarer en økt overlevelsessjanse på hele 30 \% (95\% KI 4-49) i første levemåned og 25 \% (95\% KI 7-40) ved et halvt års alder.

- India er et av landene i verden med høyest forekomst av lav fødselsvekt, der så mye som en firedel av de nyfødte er under normalen på 2,5 kg, sier en av forfatterne bak studien, Halvor Sommerfelt, som er professor ved Universitetet i Bergen og CISMAC-senteret, et senter for framragende forskning.

- Denne studien gir oss solid dokumentasjon på at også hjemmebasert bistand etter kengurumetoden er effektivt, sier han.

Studien omfattet ikke barn som veide mindre enn 1,8 kg, ettersom svært små barn og barn som er syke, skal behandles på sykehus inntil de er stabile. Det er grunn til å tro at Verdens helseorganisasjon innen et års tid vil utvikle retningslinjer som anbefaler at barn med lav fødselsvekt som ikke har begynt med kengurumetoden på fødeinstitusjonen, bør få startet det hjemme, sier Sommerfelt.

\section{LITTERATUR:}

1. Mazumder S, Taneja S, Dube B et al. Effect of community-initiated kangaroo mother care on survival of infants with low birthweight: a randomised controlled trial. Lancet 2019;394: 1724-36.

[PubMed][CrossRef]

Publisert: 15. januar 2020. Tidsskr Nor Legeforen. DOI: 10.4045/tidsskr.19.0747

(C) Tidsskrift for Den norske legeforening 2020. Lastet ned fra tidsskriftet.no 